\title{
Estimation of evapotranspiration in the Mu Us Sandland of China
}

\author{
S. Liu ${ }^{1}$, J. Bai ${ }^{1}$, Z. Jia ${ }^{1}$, L. Jia ${ }^{2}$, H. Zhou ${ }^{3}$, and L. Lu ${ }^{4}$ \\ ${ }^{1}$ State Key Laboratory of Remote Sensing Science, School of Geography, Beijing Normal University, Beijing 100875, China \\ ${ }^{2}$ Alterra, Wageningen University and Research Centre, The Netherlands \\ ${ }^{3}$ Beijing Landview Mapping Information Technology Co., Ltd., Beijing, 100096, China \\ ${ }^{4}$ Meteorological Information Center of Beijng, Beijng Meteorological Bureau, Beijing, 100089, China
}

Received: 28 August 2009 - Published in Hydrol. Earth Syst. Sci. Discuss.: 22 September 2009

Revised: 4 March 2010 - Accepted: 11 March 2010 - Published: 24 March 2010

\begin{abstract}
Evapotranspiration (ET) was estimated from 1981-2005 over Wushen County located in the Mu Us Sandland, China, by applying the Advection-Aridity model, which is based on the complementary relationship hypothesis. We used National Oceanic and Atmospheric Administration (NOAA) Advanced Very High Resolution Radiometer (AVHRR), Moderate Resolution Imaging Spectroradiometer (MODIS), and meteorological data. Our results show that the estimated daily ET was about $4.5 \%$ higher than measurements using an Eddy Covariance (EC) system after forcing energy balance closure over an alfalfa field from 22 July 2004 to 23 August 2004. At a regional scale, the estimated monthly ET was about $8.7 \%$ lower than measurements using the EC system after forcing energy balance closure over an alfalfa field in August 2004. These results were about 3.0\% higher than ET measurements by microlysimeter over sand dunes during June 1988. From 1981 to 2005, the average annual ET and precipitation levels were $287 \mathrm{~mm}$ and $336 \mathrm{~mm}$, respectively, in Wushen County. The average annual ET varied from $230 \mathrm{~mm}$ in western parts of Wushen County to $350 \mathrm{~mm}$ in eastern parts of the county. Both inter-annual and seasonal variations in ET were substantial in Wushen County. The annual ET was $200-400 \mathrm{~mm}$ from 1981-2005, and the seasonal pattern of ET showed a single peak distribution. The cumulative ET during the June-September 2004 period was $250 \mathrm{~mm}$, which was $87 \%$ of the total annual ET. The annual ET, precipitation, and the maximum Normalized Difference Vegetation Index (NDVI $I_{\max }$ ) showed positive correlations temporally and spatially.
\end{abstract}

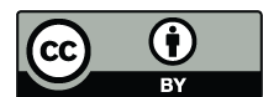

Correspondence to: S. Liu (smliu@bnu.edu.cn)

\section{Introduction}

Evapotranspiration (ET) is an indispensable component of surface energy and water balance. Accurate ET estimations play significant roles in the study of global climate change, environmental evolution, and water resource utilisation. The $\mathrm{Mu}$ Us Sandland is one of the four largest sand lands in China. It is located at the transition zone of several ecological regions with greatly altered water and heat resources, little precipitation, and an arid climate (Yao et al., 1992). In this region, drought and water shortages can adversely impact this fragile ecosystem by causing grassland degradation and land desertification. These climate variables are also key limiting factors for local economic growth and social development. Therefore, both rational exploitation and optimal utilisation of water resources are of great importance. To date, studies in the Mu Us Sandland have focused mainly on the following: dynamic landscape changes and desertification (Wu and Ci, 2002; Runnström, 2003; Yang et al., 2005); physiological and ecological characteristics of plants (Jiang and He, 1999; He and Zhang, 2003; Huang et al., 2007); dynamic monitoring of soil moisture (Lv et al., 2006); and changes in groundwater (Masakazu, 1992; Yu et al., 1998). There continues to be little known about ET in the Mu Us Sandland (Li et al., 1989; $\mathrm{Li}$ and Li, 2000). Therefore, estimations of regional ET are needed for the Mu Us Sandland, which can also be used as a reference for other arid areas in China, such as the Ejina Basin located at the lower reaches of the Heihe River.

The complementary relationship between actual and potential ET has been described by Bouchet (1963). Several models to estimate regional ET have been developed since this initial work (Morton, 1975, 1983; Brutsaert and Stricker, 1979; Granger and Gray, 1989; Sugita, 2001). These estimation approaches are attractive because only routine meteorological data (no runoff and soil moisture data) are needed. In

Published by Copernicus Publications on behalf of the European Geosciences Union. 


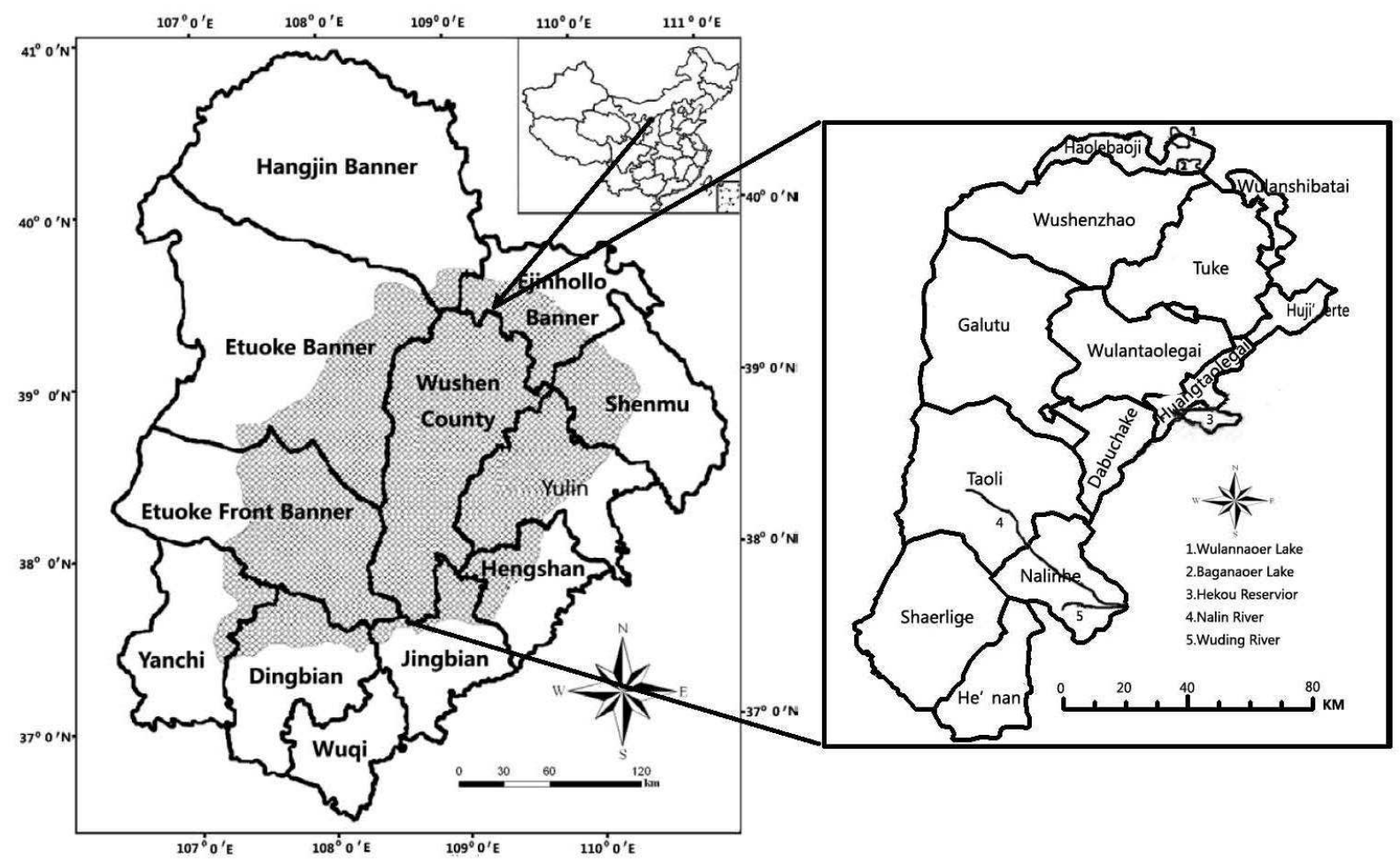

Fig. 1. Location of the Mu Su Sandland and Wushen County, China.

contrast, other ET models, including the Penman-Monteith model, Priestley-Taylor model and energy balance based model, require soil moisture, stomatal resistance, and aerodynamic resistance information, which are difficult to obtain at regional scales. Moreover, the applicability of the complementary relationship has been validated across different climate categories and land surfaces (Hobbins et al., 2001; Xu and Singh, 2004; Ramirez et al., 2005; Liu et al., 2006; Virginia et al., 2008). As a result, the Advection-Aridity model has been chosen to estimate regional ET in the Mu Us Sandland.

Using the $\mathrm{Mu}$ Us Sandland, Wushen County, Inner Mongolia as a case study, the objectives of our research were as follows: (1) to estimate regional ET using the AdvectionAridity model and by applying National Oceanic and Atmospheric Administration (NOAA) Advanced Very High Resolution Radiometer (AVHRR) and Moderate Resolution Imaging Spectroradiometer (MODIS) remote sensing data and meteorological data; (2) to validate the results of the Advection-Aridity model at local and regional scales; (3) to analyse the temporal and spatial distributions of ET in Wushen county; and (4) to analyse relationships between ET and precipitation, as well as the maximum Normalized Difference Vegetation Index $\left(\mathrm{NDVI}_{\max }\right)$.

\section{Materials and methods}

\subsection{Study area and data}

The Mu Us Sandland $\left(37^{\circ} 27.5^{\prime} \mathrm{N}-39^{\circ} 22.5^{\prime} \mathrm{N}, 107^{\circ} 20^{\prime} \mathrm{E}-\right.$ $110^{\circ} 30^{\prime} \mathrm{E}$ ) is located at the junction of the Ningxia Hui Autonomous Region, Inner Mongolia Autonomous Region, and Shaanxi Province. It includes the southern Ih Ju League, Inner Mongolia, northern Yulin, Shaanxi Province, and northeastern Yanchi, Ningxia Hui Autonomous Region. The total area of this region is $40000 \mathrm{~km}^{2}$. It is at the transition zone of the Ordos Plateau and Loess Plateau and is associated with a continental semi-arid climate. As shown in Fig. 1, the shaded area denotes the Mu Us Sandland in Wushen County $\left(37^{\circ} 38^{\prime} 54^{\prime \prime} \mathrm{N}-39^{\circ} 23^{\prime} 50^{\prime \prime} \mathrm{N}, 108^{\circ} 17^{\prime} 36^{\prime \prime} \mathrm{E}-\right.$ $109^{\circ} 40^{\prime} 22^{\prime \prime}$ E, $1300 \mathrm{~m}$ a.s.l., total area is $11645 \mathrm{~km}^{2}$ ). From 1958-1990, the annual mean temperature in Wushen County was $6.4^{\circ} \mathrm{C}$, and the annual mean precipitation was $362 \mathrm{~mm}$ (Wushenqi Chorography, 2001). Forestlands are mainly located in the northeastern and southeastern parts of Wushen County, accounting for $11 \%$ of the total area. Sandlands dominate most of the northwestern and central areas, accounting for $23 \%$ of the total area. Grasslands are distributed mainly in the southwestern and central areas, constituting about $64 \%$ of the total area. Croplands occupy nearly $2 \%$ of the land area. 
Table 1. Meteorological stations in and around Wushen County.

\begin{tabular}{lccccc}
\hline $\begin{array}{l}\text { Station name } \\
\text { (Province) }\end{array}$ & Latitude & Longitude & Elevation & Start Date & End Date \\
\hline $\begin{array}{l}\text { EtuokeBanner } \\
\text { (Inner Mongolia) }\end{array}$ & $39^{\circ} 06^{\prime} \mathrm{N}$ & $107^{\circ} 59^{\prime} \mathrm{E}$ & 1380.3 & Jan 1981 & Dec 2005 \\
$\begin{array}{l}\text { Dongsheng } \\
\text { (Inner Mongolia) }\end{array}$ & $39^{\circ} 50^{\prime} \mathrm{N}$ & $109^{\circ} 59^{\prime} \mathrm{E}$ & 1460.4 & Jan 1981 & Dec 2005 \\
$\begin{array}{l}\text { Ejinhollo Banner } \\
\text { (Inner Monglia) }\end{array}$ & $39^{\circ} 34^{\prime} \mathrm{N}$ & $109^{\circ} 44^{\prime} \mathrm{E}$ & 1329.3 & Jan 1981 & Feb 1995 \\
$\begin{array}{l}\text { Hequ } \\
\text { (Shanxi) }\end{array}$ & $39^{\circ} 23^{\prime} \mathrm{N}$ & $111^{\circ} 09^{\prime} \mathrm{E}$ & 861.5 & Jan 1981 & Dec 2005 \\
$\begin{array}{l}\text { Yulin } \\
\text { (Shaanxi) }\end{array}$ & $38^{\circ} 14^{\prime} \mathrm{N}$ & $109^{\circ} 42^{\prime} \mathrm{E}$ & 1057.5 & Jan 1981 & Dec 2005 \\
$\begin{array}{l}\text { Yanchi } \\
\text { (Ningxia Hui }\end{array}$ & & & & & \\
$\begin{array}{l}\text { Autonomous Region) } \\
\text { Dingbian } \\
\text { (Shaanxi) }\end{array}$ & $37^{\circ} 47^{\prime} \mathrm{N}$ & $107^{\circ} 24^{\prime} \mathrm{E}$ & 1347.8 & Jan 1981 & Dec 2005 \\
$\begin{array}{l}\text { Wuqi } \\
\text { (Shaanxi) }\end{array}$ & $37^{\circ} 35^{\prime} \mathrm{N}$ & $107^{\circ} 35^{\prime} \mathrm{E}$ & 1360.3 & Jan 1989 & Dec 2005 \\
$\begin{array}{l}\text { Hengshan } \\
\text { (Shaanxi) }\end{array}$ & $36^{\circ} 50^{\prime} \mathrm{N}$ & $108^{\circ} 11^{\prime} \mathrm{E}$ & 1272.6 & Jan 1981 & Dec 2005 \\
$\begin{array}{l}\text { Wushenzhao } \\
\text { (Inner Mongolia) }\end{array}$ & $37^{\circ} 56^{\prime} \mathrm{N}$ & $109^{\circ} 14^{\prime} \mathrm{E}$ & 1111 & Jan 1981 & Dec 2005 \\
$\begin{array}{l}\text { Wushenqi } \\
\text { (Inner Mongolia) }\end{array}$ & $38^{\circ} 36^{\prime} \mathrm{N}$ & $108^{\circ} 51^{\prime} \mathrm{E}$ & 1302 & Jan 1999 & Dec 2003 \\
$\begin{array}{l}\text { Research Center } \\
\text { (Inner Mongolia) }\end{array}$ & $38^{\circ} 59^{\prime} \mathrm{N}$ & $109^{\circ} 09^{\prime} \mathrm{E}$ & 1320 & Jan 1987 & Dec 1991 \\
\hline
\end{tabular}

Monthly meteorological data used in this paper were collected from 12 stations in and around Wushen County (Table 1) between 1981 and 2005. These data included mean temperatures, maximum and minimum temperatures, sunshine percentages, wind speeds, actual vapour pressures, and surface temperatures. Meteorological data from 12 meteorological stations were interpreted spatially using $1 \times 1 \mathrm{~km}$ grids. We converted air temperatures to corresponding "sea level" values according to the altitude of each station. The interpolated air temperatures were then converted to actual air temperatures using Digital Elevation Model (DEM) data. The Kriging method was used to interpolate air temperatures, wind speeds, sunshine percentages, actual water vapour pressures, and surface temperatures, while the Gradient plus Inverse-Distance-Squared (GIDS) method was used for our precipitation estimates (Nalder and Wein, 1998).

Observation data include ET and ancillary data measurements in the $\mathrm{Mu}$ Us Sandland Exploitation and Control Research Centre ("Research Centre") from 22 July 200431 August 2004. A set of Eddy Covariance (EC) System was installed in an alfalfa field $\left(38^{\circ} 58^{\prime} 58^{\prime \prime} \mathrm{N}, 109^{\circ} 07^{\prime} 43^{\prime \prime} \mathrm{E}\right.$; Campbell, CAST3; LI-7500 with observation height $1.55 \mathrm{~m}$ ). An Automatic Weather Station (AWS) was also located near the EC observation area to obtain measurements of net radiation (Q7, $1.5 \mathrm{~m}$ height), soil heat flux (Campbell, HFT3, $0.02 \mathrm{~m}$ below surface), air temperature and humidity (Vaisala, HMP45C, $1 \mathrm{~m}$ height), and wind speed (RM Young, 05103, $1 \mathrm{~m}$ height). EC data were collected at a $10 \mathrm{~Hz}$ sampling rate with a CR5000 data logger (Campbell, USA), while the AWS was sampled every $30 \mathrm{~s}$ with a CR10X data logger (Campbell, USA). These sampling rates were averaged to $30 \mathrm{~min}$. Higher quality EC data were obtained through careful data processing and quality controls, including spike detection, water $\left(\mathrm{H}_{2} \mathrm{O}\right)$ /carbon dioxide $\left(\mathrm{CO}_{2}\right)$ lag correction relative to vertical wind component, sonic virtual temperature correction, coordinating rotation using the planar fit method, air density fluctuation correction (WPL), and frequency response correction. These corrections were made using the EdiRe software package (Edinburgh University, http://www.geos.ed.ac.uk/abs/research/ micromet/EdiRe). Thirty minute flux data were screened using the following four steps: (1) rejecting data when the sensor was malfunctioning (e.g., when fault diagnostic signals exist); (2) rejecting data one hour before or after precipitation events; (3) rejecting incomplete $30 \mathrm{~min}$ data when the missing ratio was $>3.0 \%$ of the $30 \mathrm{~min}$ raw data record; and (4) 
rejecting data at night when turbulent mixing was weak (the friction velocity $\left.\mathrm{u}_{*}<0.1 \mathrm{~m} / \mathrm{s}\right)$. Only data with $\mathrm{u}_{*}>0.1 \mathrm{~m} / \mathrm{sec}$ were used (Blanken et al., 1998). Data gaps were filled using nonlinear regression (Alavi et al., 2006). A second power function between the latent heat flux and net radiation was established according to data from adjacent \pm 10 days of missing values. The missing value was filled by the regression equation if the coefficient of determination $\left(R^{2}\right)$ was $>0.5$; more data were required to form the regression equation if the $R^{2}$ was $<0.5$. The Energy Closure Ratio of EC measurement was 0.85 in the alfalfa field, so sensible and latent heat fluxes were corrected for closure by the "Bowen-Ratio Closure" method (Twine et al., 2000).

Ground data used in this study also included ET measurements by microlysimeters at the top, middle, and lower layers of sand dunes located at the Research Centre's eastern experimental site $\left(38^{\circ} 59^{\prime} \mathrm{N}, 109^{\circ} 10^{\prime} \mathrm{E}\right)$ during June and July 1988. The June 1988 ET was obtained from microlysimeter measurements every hour over a five-day period (Masakazu, 1992).

Remote sensing data used in this study included surface albedo and NDVI data. The monthly surface albedo from 1981 to 2000 was calculated using first and second band reflectance from the NOAA Pathfinder/AVHRR $(8 \times 8 \mathrm{~km})$ land data sets (Valiente et al., 1995):

$r=0.545 r_{1}+0.320 r_{2}+0.035$

where $r$ is the broad band albedo and $r_{1}$ and $r_{2}$ are the reflectance of NOAA/AVHRR in the first and second band, respectively. Judgement of remote sensing images was carried out to reject high reflectance contaminated by clouds. Monthly mean reflectance data were obtained by averaging three, 10-day images per month. These data were then resampled spatially to $1 \times 1 \mathrm{~km}$.

The monthly surface albedo from 2001-2005 was calculated every 16 days with the MODIS products of black-sky albedo $r_{\text {dir }}$ and white-sky albedo $r_{\text {dif }}$. The monthly mean albedo was obtained by averaging two 16-day images per month, and the 16-day average surface albedo was derived using the following equation (Eq. 2):

$r=(1-s) \cdot r_{\mathrm{dir}}+s \cdot r_{\mathrm{dif}}$

where $s$ is the ratio of diffuse radiation to the global radiation. The monthly value was determined by long-term ground measurements in Ejinhollo Banner from January 1961 to December 1991. Thus, seasonal values of $0.42,0.36,0.32$, and 0.33 were obtained for spring, summer, autumn, and winter, respectively.

NDVI values from 1981 to 2005 were collected from 8-km NDVI datasets of Global Inventory Modelling and Mapping Studies (GIMMS). Remote sensing data were processed by Empirical Mode Decomposition methods to remove the effects of atmospheric and radiometric calibrations on NDVI values. The image was transformed from an original isometric projection to an Albers Equal area projection. Interannual variation of vegetative coverage conditions was analysed based on the annual NDVI max $_{\text {from 1981-2005, which }}$ were constructed by selecting pixels with the maximum NDVI over 12 months. The NDVI $I_{\max }$ represents the level of vegetative coverage in the best growing season per year.

DEM data (1:250000) were collected from HYDRO1K datasets supplied by the US Geological Survey's (USGS) Earth Resources Observation and Science (EROS) Data Centre. These data were then transformed to the Albers Equal area projection.

\subsection{Model and methodology}

For homogeneous surfaces at regional scales $(1-10 \mathrm{~km})$, Bouchet (1963) proposed that the actual ET $\left(\mathrm{ET}_{a}\right)$ equals the potential ET $\left(\mathrm{ET}_{P}\right)$ when external available energy remains constant and water supply is sufficient. This type of ET is referred to as a humid environment $\mathrm{ET}\left(\mathrm{ET}_{w}\right)$. The $\mathrm{ET}_{a}$ is reduced when water becomes limited. Surface energy that is not evaporated increases the temperature and humidity gradients of the atmospheric surface layer, causing an increase in the $\mathrm{ET}_{P}$. When there is no advection, an increase in the $\mathrm{ET}_{P}$ would be equal to a decrease in the $\mathrm{ET}_{a}$. The complementary relationship between the $\mathrm{ET}_{a}$ and $\mathrm{ET}_{P}$ is expressed as (Bouchet, 1963):

$\mathrm{ET}_{P}+\mathrm{ET}_{a}=2 \mathrm{ET}_{w}$

Brutsaert and Stricker (1979) put forward the AdvectionAridity model based on the principle above, and the equation can be expressed as:

$\mathrm{ET}_{a}=2 \alpha \frac{\Delta}{\Delta+\gamma}\left(R_{\mathrm{n}}-G\right)-\left[\frac{\Delta}{\Delta+\gamma}\left(R_{\mathrm{n}}-G\right)+\frac{\gamma}{\Delta+\gamma} E_{A}\right]$

where $\alpha$ is the Priestley-Taylor coefficient, $\Delta\left(\mathrm{hpa} /{ }^{\circ} \mathrm{C}\right)$ is the slope of the saturation vapour pressure to air temperature, $\gamma$ (hpa/ $/{ }^{\circ} \mathrm{C}$ ) is the psychrometric constant, $G\left(\mathrm{Wm}^{-2}\right)$ is the soil heat flux, and $E_{A}\left(\mathrm{Wm}^{-2}\right)$ is the "drying power of the air". The $R_{\mathrm{n}}\left(\mathrm{Wm}^{-2}\right)$ is the monthly net radiation at the surface and is given by:

$R_{\mathrm{n}}=(1-r) Q-R_{\mathrm{nl}}$

where $R_{\mathrm{nl}}\left(\mathrm{Wm}^{-2}\right)$ is the net long-wave radiation, and the monthly global solar radiation $Q\left(\mathrm{Wm}^{-2}\right)$ is calculated from astronomical radiation $Q_{0}\left(\mathrm{Wm}^{-2}\right)$ and sunshine percentage $S$. The monthly astronomical radiation can be obtained by summing daily astronomical radiation. Thus, the monthly global solar radiation $Q$ is given by:

$Q=Q_{0}(a+b \cdot S)$

where $a$ and $b$ are empirical coefficients fitted by the least squares method using radiation data from the Dongsheng station from 1992-2008 (Table 2). These data were combined 
Table 2. Empirical coefficients $a$ and $b$, in different seasons in Dongsheng station from 1992-2008.

\begin{tabular}{lcccc}
\hline Season & $a$ & $b$ & samples & $\begin{array}{c}\text { Relative } \\
\text { coefficient }\left(r^{2}\right)\end{array}$ \\
\hline Spring (3-5) & 0.2865 & 0.4167 & 50 & 0.967 \\
Summer (6-8) & 0.2227 & 0.4693 & 51 & 0.889 \\
Autumn (9-11) & 0.1539 & 0.5691 & 51 & 0.949 \\
Winter (12,1,2) & 0.2698 & 0.4425 & 51 & 0.939 \\
\hline
\end{tabular}

with astronomical radiation values and sunshine percentages after data quality was confirmed.

The net longwave radiation $R_{\mathrm{nl}}\left(\mathrm{Wm}^{-2}\right)$ is estimated as (Zeng, 2004):

$$
R_{\mathrm{nl}}=\varepsilon \sigma T_{a}^{4}\left(a_{0}+a_{1} \sqrt{e_{a}}\right)\left[b_{0}+\left(1-b_{0}\right) S\right]+\Delta R_{\mathrm{nl}}
$$

where $\varepsilon$ is surface emissivity and assumed to be 0.95 for this work, $\sigma$ is the Stephan-Boltzman constant, $T_{a}(\mathrm{~K})$ is the air temperature, $e_{a}(\mathrm{hpa})$ is the actual vapour pressure, and $a_{0}$, $a_{1}$, and $b_{0}$ are empirical coefficients fitted by Zeng (2004) with monthly average data at 17 radiation stations throughout China from 1993 to 2001 (Table 3). The $\Delta R_{\mathrm{nl}}\left(\mathrm{Wm}^{-2}\right)$ is the radiation correction term expressed as: $\Delta R_{\mathrm{nl}}=\varepsilon \sigma T_{0}^{4}-$ $\varepsilon \sigma T_{a}^{4}$, where $T_{0}(\mathrm{~K})$ is the surface temperature.

The soil heat flux $G\left(\mathrm{Wm}^{-2}\right)$ is estimated as (Allen et al., 1998):

$G=0.07 \frac{10^{6}}{24 \cdot 60 \cdot 60}\left(T_{i+1}-T_{i-1}\right)$

where $T_{i-1}$ and $T_{i+1}\left({ }^{\circ} \mathrm{C}\right)$ are the monthly mean air temperatures of the preceding month and the next month, respectively.

The drying power of the air $E_{A}\left(\mathrm{Wm}^{-2}\right)$ can be written as:

$E_{A}=0.26 \cdot 2.4702 \frac{10^{6}}{24 \cdot 60 \cdot 60}\left(e_{s}-e_{a}\right)(1+c u)$

where $\mathrm{e}_{s}(\mathrm{hpa})$ is the saturated vapour pressure at a reference height $(1.5 \mathrm{~m})$, and $u(\mathrm{~m} / \mathrm{s})$ is the wind speed at $2 \mathrm{~m}$ above the ground; $c$ is the calibrated wind coefficient calculated as (Prere and Popov, 1979):

$c= \begin{cases}0.54 & T_{\max }-T_{\min } \leq 12^{\circ} \mathrm{C} \text { or } T_{\min } \leq 5^{\circ} \mathrm{C} \\ 0.07\left(T_{\max }-T_{\min }\right)-0.265 & T_{\min }>5^{\circ} \mathrm{C}, 12^{\circ} \mathrm{C}<T_{\max }-T_{\min } \leq 16^{\circ} \mathrm{C} \\ 0.89 & T_{\min }>5^{\circ} \mathrm{C}, 16^{\circ} \mathrm{C}<T_{\max }-T_{\min }\end{cases}$

where $T_{\max }$ and $T_{\min }\left({ }^{\circ} \mathrm{C}\right)$ are the monthly maximum and minimum air temperatures, respectively.

At local scales, the $E_{A}$ per $30 \mathrm{~min}$ can be expressed as (Parlange and Katul, 1992):

$E_{A}=\frac{\rho k^{2} C_{P} u_{1} \gamma^{-1}\left(e_{s}^{*}-e_{a}^{*}\right)}{\left[\ln \left(\frac{z_{1}-d}{z_{0 m}}\right)-\Psi_{m}\left(\frac{z_{1}-d}{L}\right)\right]\left[\ln \left(\frac{z_{2}-d}{z_{0 h}}\right)-\Psi_{h}\left(\frac{z_{2}-d}{L}\right)\right]}$

where $\rho\left(\mathrm{kg} / \mathrm{m}^{3}\right)$ is the air density, $\kappa$ is von Karman's constant with a value of $0.41, C_{p}\left(1013 \mathrm{~J} / \mathrm{kg}^{\circ}\right)$ is the specific
Table 3. Empirical coefficients $a_{0}, a_{1}$, and $b_{0}$ of each month in 17 radiation stations from 1993-2001.

\begin{tabular}{cccc}
\hline Month & $a_{0}$ & $a_{1}$ & $b_{0}$ \\
\hline 1 & 0.495 & -0.071 & 0.250 \\
2 & 0.508 & -0.070 & 0.196 \\
3 & 0.514 & -0.068 & 0.204 \\
4 & 0.509 & -0.072 & 0.269 \\
5 & 0.515 & -0.069 & 0.192 \\
6 & 0.499 & -0.068 & 0.276 \\
7 & 0.500 & -0.068 & 0.214 \\
8 & 0.515 & -0.072 & 0.247 \\
9 & 0.492 & -0.069 & 0.275 \\
10 & 0.495 & -0.070 & 0.247 \\
11 & 0.500 & -0.071 & 0.216 \\
12 & 0.504 & -0.075 & 0.239 \\
\hline
\end{tabular}

heat of air at a constant pressure, $u_{1}(\mathrm{~m} / \mathrm{s})$ is the wind velocity at the height $z_{1}(\mathrm{~m}), e_{s}^{*}$ and $e_{a}^{*}$ (hpa) are the saturated and actual vapour pressures at air temperatures at a height of $z_{2}(\mathrm{~m})$ above the ground surface, respectively. The zero plane displacement height $d(\mathrm{~m})$ is calculated as $2 / 3$ of the vegetation height $h$, and the momentum roughness length $z_{\mathrm{om}}(\mathrm{m})$ was calculated with EC data based on the method proposed by Yang et al. (2003). The roughness length for heat transfer $z_{\text {oh }}(\mathrm{m})$ in terms of $z_{0 h}=z_{0 \mathrm{~m}} / \exp \left(\mathrm{kB}^{-1}\right)$ can be parameterised according to $\mathrm{kB}^{-1}=2.46\left(R e^{*}\right)^{0.25}-2$, where $R e^{*}$ is the roughness Reynolds number (Brutsaert, 1982). The $L$ is the Obuhov length $(\mathrm{m})$ that is obtained from EC measurements. $\Psi_{h}$ and $\Psi_{m}$ are the integral form of the stability correction functions for heat transfer and momentum exchange, respectively. In unstable conditions, $\Psi_{h}$ and $\Psi_{m}$ can be expressed as (Paulson, 1970):

$\Psi_{m}=2 \ln \left[\frac{(1+x)}{2}\right]+\ln \left[\frac{\left(1+x^{2}\right)}{2}\right]-2 \arctan (x)+\frac{\pi}{2}$ and

$\Psi_{h}=2 \ln \left[\frac{\left(1+x^{2}\right)}{2}\right]$

In stable conditions, $\Psi_{h}$ and $\Psi_{m}$ can be expressed as (Webb, 1970; Businger et al., 1971):

$\Psi_{m}=\Psi_{h}=-5 \xi$

where

$x=(1-16 \xi)^{0.25}$

and

$\xi=(z-d) / L$

The Priestley-Taylor coefficient $\alpha$ has been determined by many authors. Priestley and Taylor (1972) chose $\alpha=1.26$ as the optimum value based on an analysis of data observed at 
sea level and large scales of saturated land surfaces. Davies and Allen (1973) used a value of 1.26 for well-watered grass. Zhang et al. (2004) found that the $\alpha$ varied substantially during the growing season and assigned values of 1.17 and 1.26 for winter wheat and 1.06 and 1.09 for maize as seasonal averages in the North China Plain for 1999 and 2000. Liu et al. (2006) discussed the Priestley-Taylor coefficient as it relates to the Yellow River Basin, where our study area is located. They indicated an optimum $\alpha$ value in the range of $1.23-1.29$ and adopted 1.26 , so 1.26 was believed to be a preferred $\alpha$ value in our study area.

\section{Results and discussion}

\subsection{Validation of ET estimation}

The Advection-Aridity model was run with meteorological and EC data at a local scale to test its performance. Data between 22 July 2004 and 23 August 2004 (except for rainy days of $24,25,30$, and 31 July and 1, 14, 15, and $20 \mathrm{Au-}$ gust) were selected to compare with estimated daily ETs over an alfalfa field studied (Fig. 2). Most data concentrated around the 1:1 line, and the estimated ET was about $4.5 \%$ higher than ground measurements, providing evidence that the Advection-Aridity model is suitable for ET estimation in the Mu Us Sandland.

The precision of the ET estimated by the AdvectionAridity model, with remote sensing data at regional scales, was validated by comparing EC measurements over the Research Centre alfalfa field from August 2004 and by examining microlysimeter measurements over sand dunes from June 1988.

The monthly, regional scale ET estimated by the Advection-Aridity model was compared with ET measurements from the EC system over an alfalfa field from August 2004. The ET derived from August 2004 measurements was $91.1 \mathrm{~mm}$, while the estimated ET of the corresponding pixel was $94.0 \mathrm{~mm}$, with an overestimation of about $3.2 \%$. However, as the Energy Closure Ratio of EC measurement was 0.85 in this period, the ET after forcing closure using the "Bowen-Ratio Closure" method (Twine et al., 2000) reached $102.9 \mathrm{~mm}$, which was about $8.7 \%$ higher than the estimated ET. Furthermore, the corresponding monthly net radiation $(\mathrm{Rn})$ was validated with ground measurements. The estimated $\mathrm{Rn}$ of $106.5 \mathrm{~W} \mathrm{~m}^{-2}$ was nearly $11.9 \%$ lower than the measured $\mathrm{Rn}$ of $120.9 \mathrm{~W} \mathrm{~m}^{-2}$ during August 2004.

According to research by Masakazu et al. (1992), the ET measured by microlysimeter over sand dunes sampled was about $1 \mathrm{~mm} /$ day based on five discontinuous days selected from June 1988. These results agreed with results of the simple method for estimating the ET rate from a dry sand surface ( $\mathrm{Li}$ and $\mathrm{Li}, 2000$ ). Consequently, the monthly ET was about
$30 \mathrm{~mm}$ in June 2004. However, the estimated ET of the corresponding pixel was $30.9 \mathrm{~mm}$, which is about $3.0 \%$ higher than the ET measured by microlysimeter.

Generally, precisions of regional ET estimations over different surfaces were acceptable, indicating reasonable performance of the model in estimating monthly ET in the Mu Us Sandland. This conclusion considered representations and errors associated with ground measurements, as well as the pixel-mixing problem at local and regional scales.

\subsection{Spatial pattern of ET in Wushen County}

The spatial pattern of annual mean ET generated from the Advection-Aridity model in Wushen County during 19812005 is presented in Fig. 3. The ET in Wushen County increased spatially from northwest to southeast. The annual mean ET in this region was $287 \mathrm{~mm}$ during the 1981-2005 period, varying from $230 \mathrm{~mm}$ in the northwest to $350 \mathrm{~mm}$ in the southeast. The corresponding precipitation was $336 \mathrm{~mm}$ in this area. In the northwestern region, including the west of Wushen Zhao and Galutu, the ET was within $230-260 \mathrm{~mm}$. In the northeastern (Wulanshibatai, Hujierte, and Huangtaolegai) and southeastern (Nalinhe and Henan) areas of Wushen County, the ET varied between 310-350 mm. In other areas, the ET was between $260-310 \mathrm{~mm}$. The Wuding River Basin and the Nalin River Basin located in the southeastern section of Wushen County and the Hekou Reservoir to the east made the ET much higher than other regions. The ET in the northeastern part of Wushen County was higher because most areas of this region were covered with forestland and contain the Bage Nur and Wulan Nur Lakes. In northwestern parts of the county, the lower ET could be attributed to fixed or mobile sand dunes distributed across most of this area. Figure 4 shows the spatial distribution of relative variability of annual mean ET in Wushen County. The formula used can be expressed as:

$\operatorname{var}_{\mathrm{avg}}=\frac{1}{n} \sum_{i=1}^{n}\left|\frac{\mathrm{ET}_{\mathrm{ai}}-\mathrm{ET}_{\mathrm{avg}}}{\mathrm{ET}_{\mathrm{avg}}}\right|$

where var $_{\text {avg }}$ is the relative variability, $\mathrm{ET}_{\mathrm{ai}}$ is the annual $\mathrm{ET}$ per year, and $\mathrm{ET}_{\mathrm{avg}}$ is the annual mean ET during the period 1981-2005.

The relative variability of the annual ET in Wushen County was between $11-25 \%$. The relative variability in northwestern parts of the county (west of Wushen Zhao and Galutu) was between $20-25 \%$, which is higher than other areas. In eastern parts of Wushen County (Wulanshibatai, Hujierte, Huangtaolegai, Dabuchake, Nalinhe, and Henan), because large areas are covered with forestland and rivers, the relative variability of the annual ET was between 11$14 \%$. In other areas, the annual ET varied from $14-20 \%$. All together, the relative variability of annual ET in Wushen County decreased spatially from the northwest to southeast. 


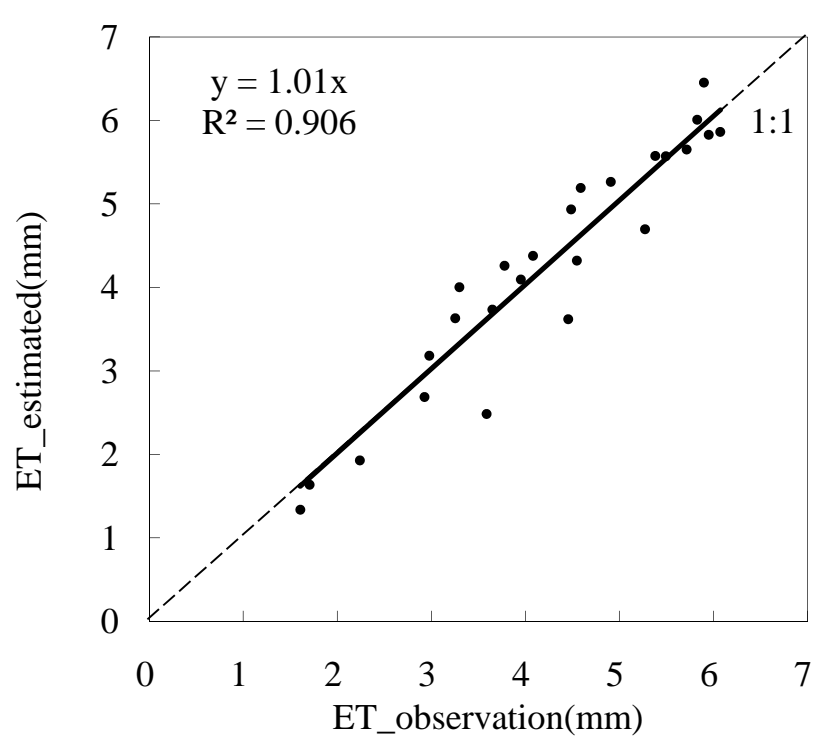

Fig. 2. Comparisons between estimated evapotranspiration (ET) and measured ET over an alfalfa field by Eddy Covariance (EC) system after an "Energy Closure Correction" from 22 July 2004-23 August 2004.

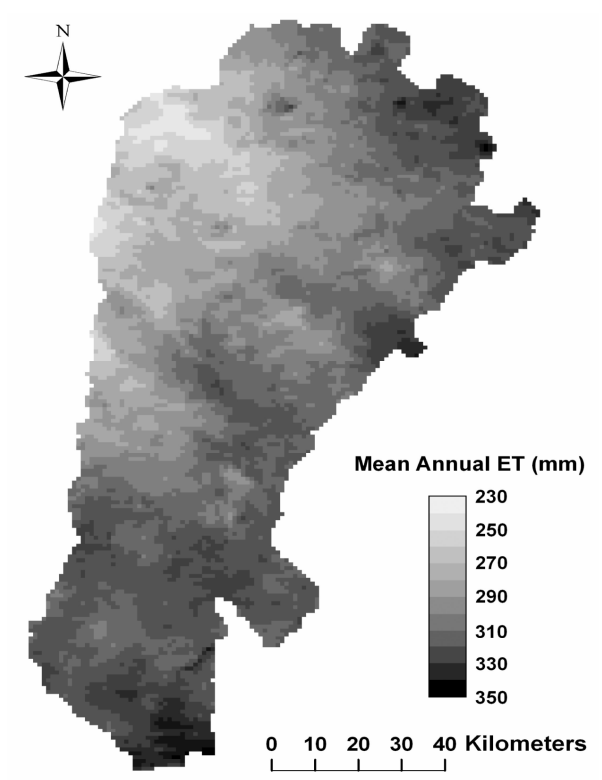

Fig. 3. The spatial pattern of annual mean evapotranspiration (ET; $\mathrm{mm}$ ) in Wushen County during 1981-2005.

Spatial patterns of annual ET in Wushen County from 1981-2005 are displayed in Fig. 5. Although the annual ET varied substantially from year-to-year, the spatial pattern of annual ET was consistent and increased from west to east, which was mainly attributable to more sand dunes being distributed to the county's west, while more forestlands and rivers are located in eastern parts of Wushen County. The re-

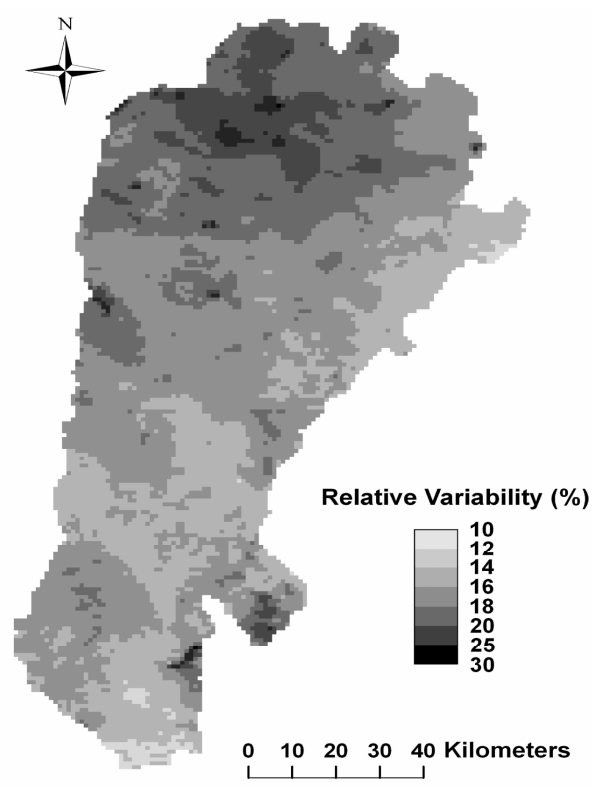

Fig. 4. Spatial patterns of relative variability of annual mean evapotranspiration (ET) in Wushen County from 1981-2005.

gion of higher ET extended to the west and lower ET regions were reduced in wet years. Conversely, the region of lower ET extended to the east and the higher ET region shrank during dry years.

\subsection{Temporal variation of ET in Wushen County}

The variation of annual ET, as well as ET and precipitation departures in Wushen County, during 1981-2005 are shown in Fig. 6. The annual ET in Wushen County was larger than $300 \mathrm{~mm}$ in $1985,1988,1991,1992,1996,1998,2002,2003$, and 2004. The annual ET even exceeded $350 \mathrm{~mm}$ in 1996 , 1998, 2002, and 2003 and was much higher than those of other years. In 1982 and 1987, the annual ET was about $200 \mathrm{~mm}$, which was much lower than other years. Figure 6 also indicates that ET and precipitation departures have the same sign in most years, except for 1991, 1994, 1995, 1999, and 2001, which were wet to dry (or dry to wet) transitional years. The ET departures had a lag effect compared to precipitation departures during these years. The annual ET departures in 1998, 2002, and 2003 were above $70 \mathrm{~mm}$, and negative departures were measured in 1982 and 1987. The ET departures were between 30-70 mm from 1996-2004, while the ET departures were negative in 1983, 1989, 1993, 1994, and 2005. For other years, annual ET departures were less than $30 \mathrm{~mm}$. In general, the inter-annual variation of ET in Wushen County was significant.

Figure 7 depicts the monthly mean ET and precipitation variation in Wushen County during 1981-2005. Variations in monthly mean ET and precipitation were similar after a single peak distribution. Most ET in Wushen County was 

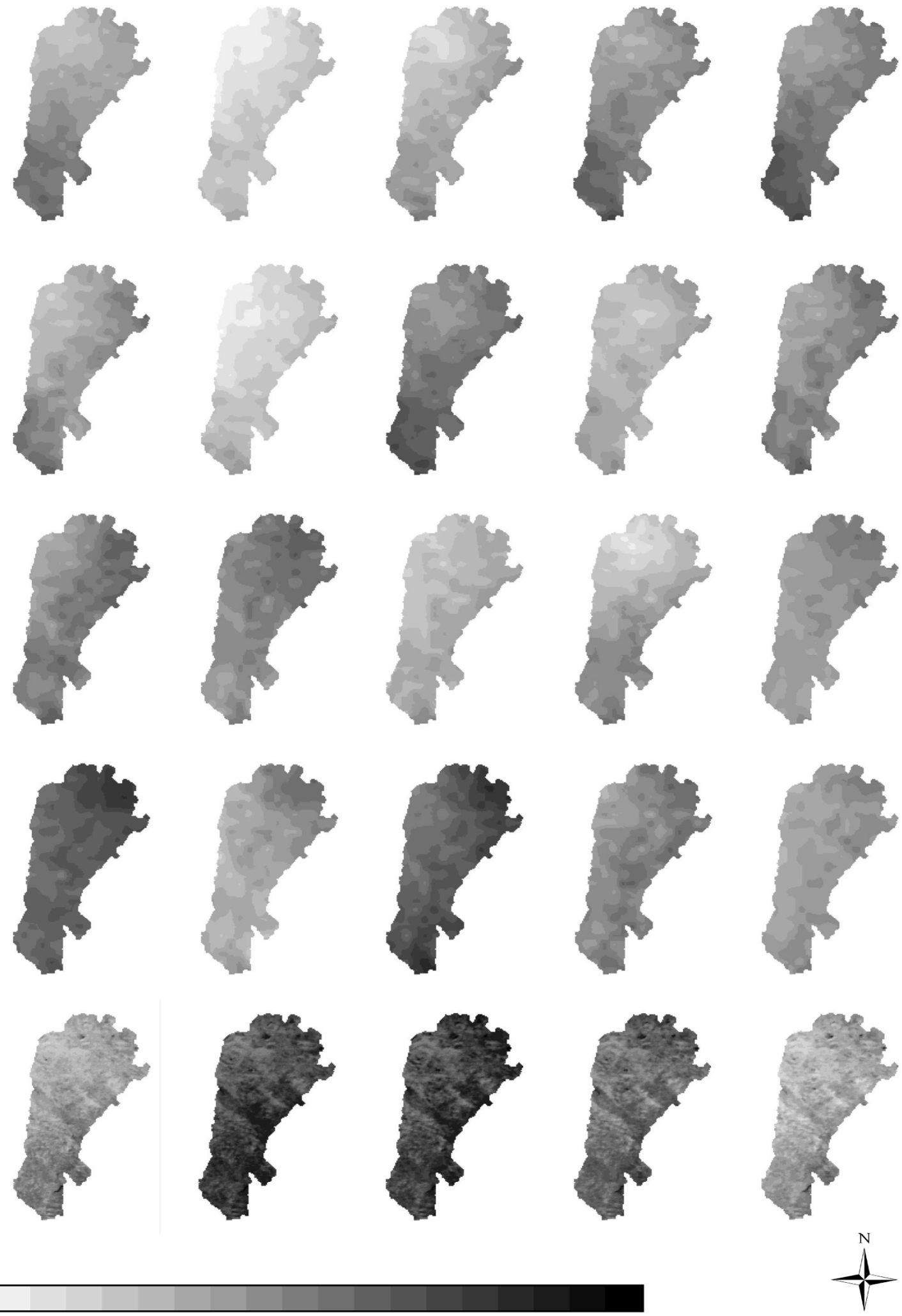

$\begin{array}{lllllllllllllllllll}140 & 160 & 180 & 200 & 220 & 240 & 260 & 280 & 300 & 320 & 340 & 360 & 380 & 400 & 420 & 440 & 500 & 550 & >550\end{array}$ Annual ET (mm)

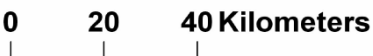

Fig. 5. Spatial patterns of annual evapotranspiration (ET) in Wushen County from 1981-2005. 


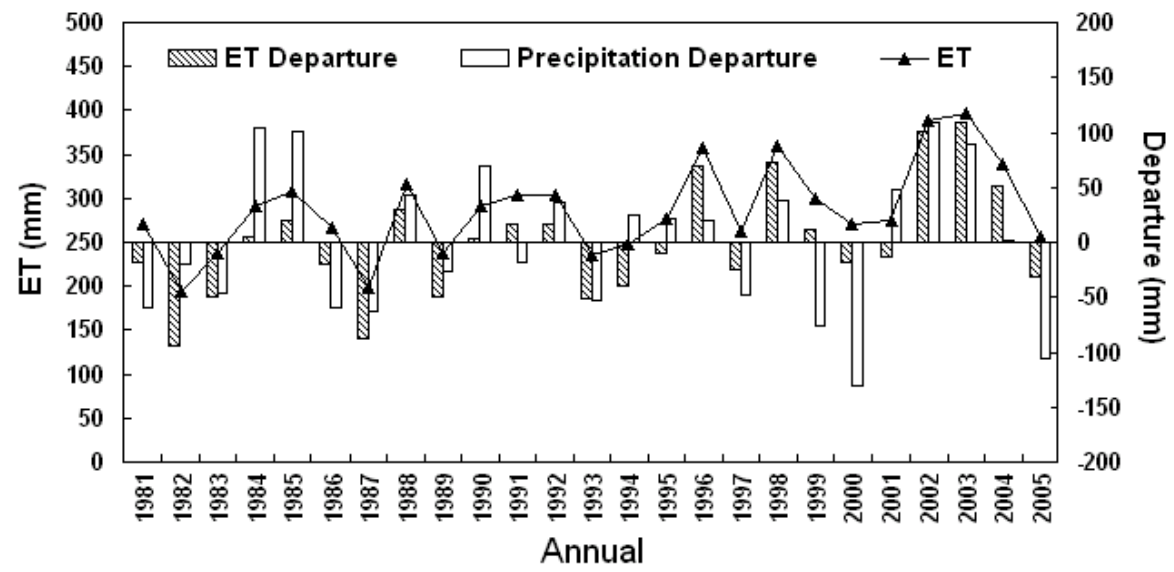

Fig. 6. Variations and departures in annual evapotranspiration (ET) and precipitation in Wushen County from 1981-2005.

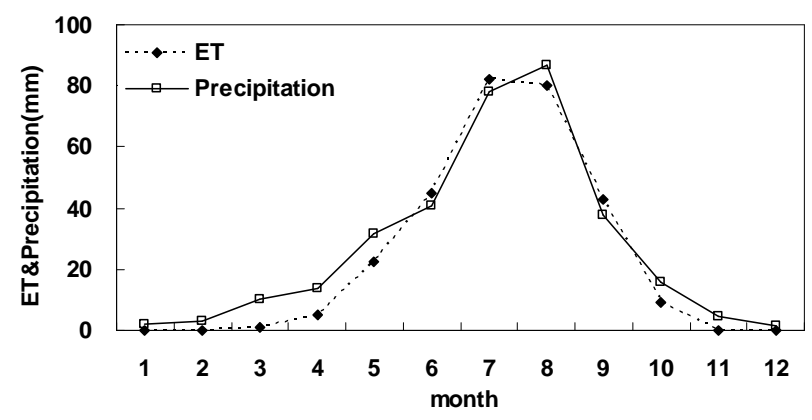

Fig. 7. Variations in monthly evapotranspiration (ET) and precipitation in Wushen County from 1981-2005.

concentrated from June-September and totalled $250 \mathrm{~mm}$, accounting for $87 \%$ of the annual amount. Precipitation over this same period was $242 \mathrm{~mm}$, which was $75 \%$ of the annual total. Figure 7 shows that in April and May, when vegetation was at early growth stages, ET increased slowly with increasing precipitation. In June, vegetation grew vigorously because of rapidly rising ambient temperatures and sunshine hours. ET during this period increased much faster than precipitation; thus, drought conditions often occurred in the late spring and early summer of this period. In Wushen County, most precipitation occurred in July and August. Substantial precipitation dissipated as ET, except for small amounts that permeated into Mu Us Sandland soils. Precipitation in September and October was reduced with decreasing air temperatures. However, large amounts of water are still needed for mature grasses and crops during this time period, so the ET during this period was maintained. During winter and spring (November-March), monthly, mean air and surface temperatures were both less than zero degrees. Thus, the ET was extremely small due to withered vegetation, low air temperatures, and seasonal freezing of soil water.

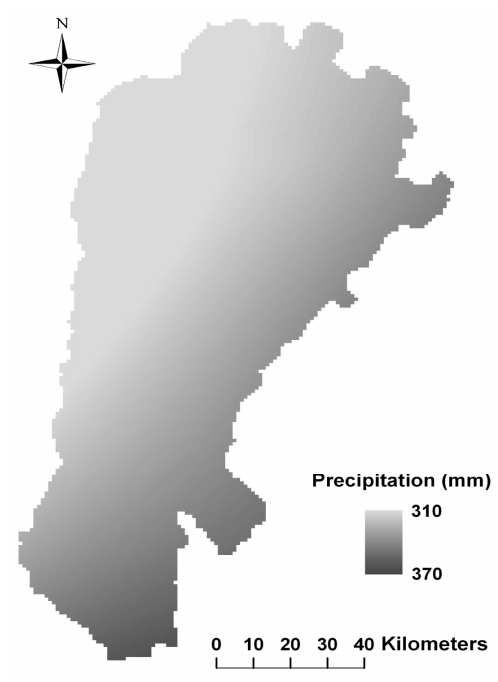

Fig. 8. Spatial distributions of annual mean precipitation in Wushen County from 1981-2005.

These results show that ET and precipitation can reach a low-level equilibrium during a given month. However, in June, July, and September, ET values were larger than precipitation levels, indicating restricted growth during these months.

\subsection{Relationships between ET and precipitation, NDVI $_{\text {max }}$ in Wushen County}

ET is mainly determined by local meteorological events, vegetative conditions, and soil water content. Because Wushen County is located in an arid/semi-arid region, main factors influencing ET levels are water condition (e.g., precipitation and soil moisture) and vegetative cover and growth status (e.g., NDVI and LAI). Thus, the relationship between ET and precipitation, as well as $\mathrm{NDVI}_{\max }$, can be analysed. 


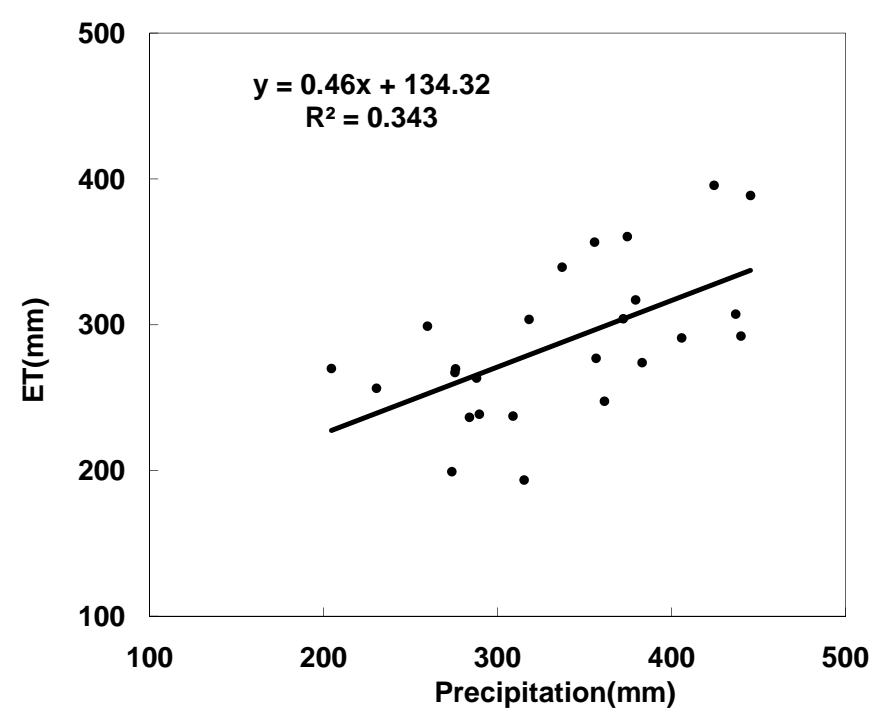

Fig. 9. Scatter plot of evapotranspiration (ET) versus precipitation in Wushen County from 1981-2005.

Spatial patterns of annual mean precipitation during 19812005 are shown in Fig. 8. The annual mean precipitation in Wushen County increased spatially from the northwest to southeast, with average precipitation of $336 \mathrm{~mm}$. For the northwestern part of Wushen County, minimum precipitation was observed $(<310 \mathrm{~mm})$. In northeastern and southeastern parts of the county, maximum precipitation occurred $(>370 \mathrm{~mm})$. Precipitation in other regions ranged from 310$370 \mathrm{~mm}$. The spatial pattern of annual mean ET was the same as precipitation levels in Wushen County. Figure 9 is the scatter plot of annual ET versus precipitation in Wushen County from 1981-2005. These results show a positive relationship between annual ET and precipitation in Wushen County $(r=0.586, n=25, p<0.01)$. In general, precipitation is a main factor influencing ET in Wushen County.

Figure 10 shows the spatial pattern of annual mean NDVI $_{\max }$ in Wushen County from 1981-2005. It presents a positive correlation between the spatial distribution of ET (Fig. 3) and NDVI $I_{\max }$, in which higher ET values were found in regions with higher $\mathrm{NDVI}_{\max }$. An increasing spatial trend from west to east was clearly observed in the $\mathrm{NDVI}_{\max }$ distribution. A positive correlation is exhibited between $\mathrm{NDVI}_{\max }$ and ET values in Wushen county from 1981-2005 (Fig. 11; $r=0.448, n=25, p<0.05$ ). In general, the ET was high in years with well-developed vegetation and high coverage, while relatively low ETs were measured in years with poor growth conditions and low vegetative coverage.

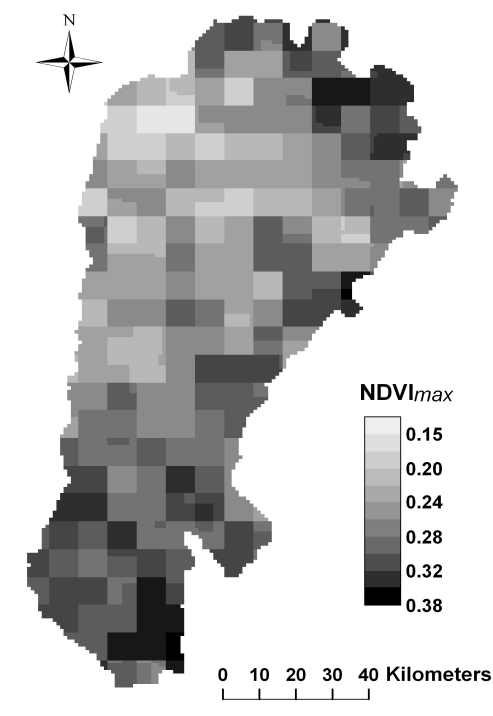

Fig. 10. Spatial distributions of NDVImax in Wushen County from 1981-2005.

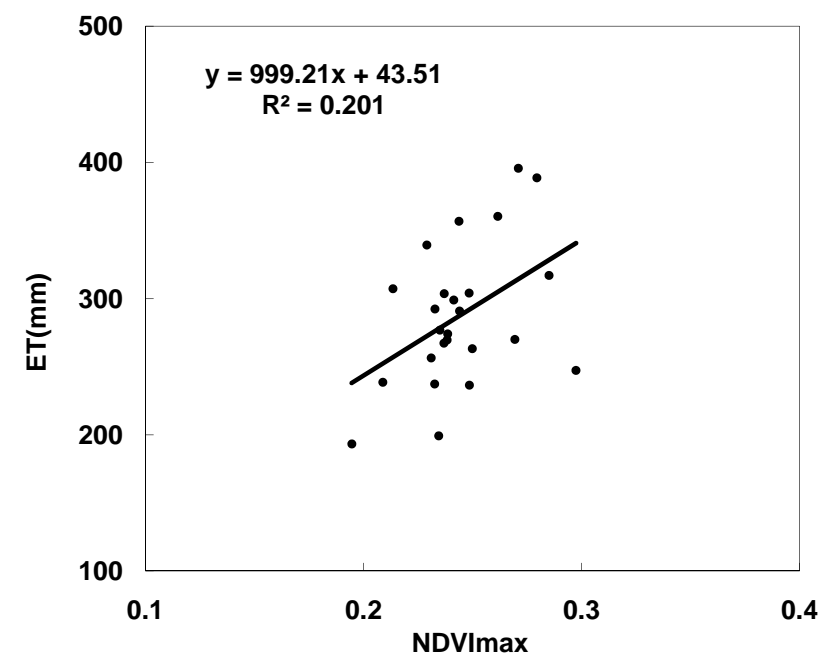

Fig. 11. Scatter plot of evapotranspiration (ET) versus NDVI $I_{\max }$ in Wushen County from 1981-2005.

\section{Conclusions}

Remote sensing and meteorological data were used to calculate ET values in Wushen County, located in the Mu Us Sandland, China. ET values were estimated using the AdvectionAridity model based on the complementary relationship hypothesis and were validated by ground measurements (EC system and microlysimeter). In addition, spatial and temporal distributions of ET were analysed, and several conclusions can be drawn. 
The estimated daily ET over the Research Centre alfalfa field was about $4.5 \%$ higher than ET values measured after forcing closure using the "Bowen-ratio Closure" method at a local scale from 22 July 2004 to 23 August 2004. The estimated monthly ET was also about $8.7 \%$ lower than measurements by EC after forcing closure using the "Bowen-ratio Closure" in August 2004 over the same alfalfa field. The ET was 3.0\% higher than that measured by microlysimeter over the Mu Us Sandland in June 1988. The precision of estimated Rn values during the period of ET estimation in August 2004 was 11.9\% lower than ground measurements.

The annual mean ET in Wushen County was between 230-350 mm during 1981-2005, with a spatial average of $287 \mathrm{~mm}$ increasing from west to east. The average precipitation was $336 \mathrm{~mm}$ during this same period. The relative multi-year variability of the annual ET in Wushen County was between $11-25 \%$, and this annual ET decreased spatially from the northwest to southeast. From 1981-2005, the region of higher ET extended to western parts of Wushen County, and lower ET regions shrank in wet years. During dry years, the region of lower ET extended to eastern parts of Wushen County, and the higher ET region shrank.

Inter-annual and seasonal variations in ET values across Wushen County were substantial. The maximum annual ET was close to $400 \mathrm{~mm}$, while the minimum value was approximately $200 \mathrm{~mm}$. Seasonal variations in the ET followed a single peak distribution. High ET levels occurred from JuneSeptember, averaging $250 \mathrm{~mm}$ and accounting for $87 \%$ of the annual total ET. Positive correlations were measured between annual ET, precipitation events, and $\mathrm{NDVI}_{\max }$ in both their temporal and spatial distributions.

Generally, groundwater levels were relatively stable (Masakazu, 1992), and annual mean precipitation during 1981-2005 was slightly higher than ET. Therefore, revenues and expenditures of water resources were at a low-level balance. This situation could only satisfy the growth of vegetation. Our analyses indicate non-uniformity in temporal and spatial distributions of precipitation that severely limited vegetative growth. It also affected the temporal and spatial distribution of ET. Thus, improvements in our utilisation of precipitation are essential to advancing vegetative growth and maintaining water resources in the Mu Us Sandland.

In our study, some parameters in the Advection-Aridity model, such as the Priestley-Taylor coefficient, were considered constants. These parameters require further refinements combined with land cover/use maps. As only one groundmeasured monthly ET has been used for validation, more ground measurements should be collected to validate the performance of the Advection-Aridity model at regional scales. In addition, the popular pixel mixture problem could elicit errors, especially in validations by EC and microlysimeter measurements, because the spatial resolution of remote sensing data is coarse $(1 \times 1 \mathrm{~km}$ or $8 \times 8 \mathrm{~km})$. Thus, remote sensing data with higher spatial resolutions would be informative.
Acknowledgements. This work was supported by the Hi-tech Research and Development Program of China (2007AA12Z175), National Natural Science Foundation of China (40971194), the National Basic Research Program of China (2007CB714401), and the European Commission as part of the CEOP - AEGIS project (Call FP7-ENV-2007-1 Grant no. 212921) (http://www.ceop-aegis.org).

Edited by: X. Li

\section{References}

Alavi, N., Warland, J. S., and Berg, A. A.: Filling gaps in evapotranspiration measurements for water budget studies: Evaluation of a Kalman filtering approach, Agr. Forest Meteorol., 141, 57-66, 2006.

Allen, R. G., Pereira, L. S., Raes, D., and Smith, M.: Crop evapotranspiration, FAO Irrigation and Drainage, Rome 24 pp., 1998.

Blanken, P. D., Black, T. A., Neumann, H. H., Denhartog, G., Yang, P. C., Nesic, Z., Staebler, R., Chen, W., and Novak, M. D.: Turbulence flux measurements above and below the overstory of a boreal aspen forest, Bound.-Lay. Meteorol., 89, 109-140, 1998.

Bouchet, R. J.: Evapotranspiration reele et potentielle, signification climatique, Publ., General assembly Berkeley, Int. Ass. Sci. Hydrol., Gentbrugge, Belgium, 62, 134-142, 1963.

Brutsaert, W.: Evaporation into the Atmosphere, Theory, History, and Applications, D. Reidel, Boston, MA, 1982.

Brutsaert, W., Stricker, H.: An advection-aridity approach to estimate actual regional evapotranspiration, Water Resour. Res., 15(2), 443-449, 1979.

Businger, J. A., Wyngaard C. J., Izumi Y., and Bradley E. F.: Flux profile relationships in the atmospheric surface layer, J. Atmos. Sci., 28, 181-189, 1971.

Davies, J. A. and Allen, C.D.: Equilibrium, potential and actual evaporation from cropped surfaces in Southern Ontario, J. Appl. Meteorol., 12, 649-657, 1973.

Granger, R. J., Gray, D. M.: Evaporation from natural nonsaturated surfaces, J. Hydrol., 111, 21-29, 1989.

He, W. M. and Zhang, X. S.: Responses of an evergreen shrub Sabina vulgaris to soil water and nutrient shortages in the semiarid Mu Us Sandland in China, J. Arid Environ., 53, 307-316, 2003.

Hobbins, M. T., Ramirez, J. A., Brown, T. C., and Claessens, L. H. J. M.: The complementary relationship in estimation of regional evapotranspiration: the complementary relationship areal evapotranspiration and advection - aridity models, Water Resour. Res., 37(5), 1367-1387, 2001.

Huang, D., Wang, K., and Wu, W. L.: Dynamics of soil physical and chemical properties and vegetation succession characteristics during grassland desertification under sheep grazing in an agro-pastoral transition zone in Northern China, J. Arid Environ., 70, 120-136, 2007.

Jiang, G. and He, W.: Species - and habitat - variability of photosynthesis, transpiration and water use efficiency of different plant species in Mu Us Sandland, Acta Bot. Sin., 41(10), 1114-1124, 1999.

Li, P. F. and Li, B. G.: Study on some characteristics of evaporation of sand dune and evapotranspiration of grassland in Mu Us 
Desert, J. Hydrol. Eng., 3, 24-28, 2000(in Chinese, abstract in English).

Li, Q. H., Koubayashi, T., Motada, Y., Matsuda, A., and Kamichika, M.: Evaporation characteristics of the dune sand in the Mu Us Desert, China, Journal of Agricultural Meteorology, 44(4), 301304, 1989.

Liu, S. M., Sun, R., Sun, Z. P., Li, X. W., and Liu, C. M.: Evaluation of three complementary relationship approaches for evapotranspiration over The Yellow River Basin, Hydrol. Process., 20(11), 2347-2361, 2006.

Lv, Y.Z., Hu, K.L., Li, B.G.: The spatio - temporal variability of soil water in sand dunes in Mu Us Sandland, Acta Pedologica Sinica, 43(1), 152-154, 2006(in Chinese).

Masakazu, S.: Fluctuations of groundwater level and evapotranspiration in the Mu Us Desert, Collected Papers of the Mu Us Desert Exploitation and Control Research Center. Inner Mongolia University Press, Hohhot, 120-126, 1992(in Chinese, abstract in English).

Morton, F. I.: Estimating evaporation and transpiration from climatological observations, J. Appl. Meteorol., 14(4), 488-497, 1975.

Morton, F. I.: Operational estimates of areal evapotranspiration and their significance to the science and practice of hydrology, J. Hydrol., 66, 1-76, 1983.

Nalder, I. A. and Wein, R. W.: Spatial interpolation of climatic normals: Test of a new methods in the Canadian boreal forest, Agr. Forest Meteorol., 92, 211-225, 1998.

Parlange M. B. and Katul G. G.: An Advection-Aridity Evaporation Model, Water Resour. Res., 28(1), 127-132, 1992.

Paulson, C. A.: The mathematical representation of wind speed and temperature profiles in the unstable atmospheric surface layer, J. Appl. Meteor., 9, 857-861, 1970.

Prere, M. and Popov, G. F.: Agrometeorological crop monitoring and forecasting, FAO Plant Production and Protection, Rome, 64 pp., 1979.

Priestley, C. H. B. and Taylor, R. J.: On the assessment of surface heat flux and evaporation using large-scale Parameters, Mon. Weather Rev., 100(2), 81-92, 1972.

Ramirez, J. A., Hobbins, M. T., and Brown, T. C.: Observational evidence of the complementary relationship in regional evaporation lends strong support for Bouchet's hypothesis, Geophys. Res. Lett., 32, L15401, doi:10.1029/2005GL02354, 2005.

Runnström, M. C.: Rangeland development of the Mu Us Sandy land in semiarid China: An analysis using landsat and NOAA remote sensing data, Land Degrad. Dev., 14, 189-202, 2003.

Sugita, M., Usui, J., Tamagawa, I., and Kaihotsu, I.: Complementary relationship with a convective boundary, Water Resour. Res., 37(2), 353-365, 2001.
Twine, T. E., Kustas, W. P., Normal, J. M., Cook, D. R., Houser, P. R., and Meyers T. P., Prueger, J. H., Starks, P. J., and Wesely, M. L.: Correcting eddy-covariance flux underestimates over a grassland, Agr. Forest Meteorol., 103, 279-300, 2000.

Valiente, J. A., Nunez, M., Lopez-Baeza, E., and Mereno, J. F.: Narrow-band to broad-band conversion for Meteosat-visible channel and broad-band albedo using both AVHRR-1 and -2 channels, Int. J. Remote Sens., 16(6), 1147-1166, 1995.

Virginia, V., Shafiqul, I., and Leticia, R.: Estimation of evaporative fraction and evapotranspiration from MODIS products using a complementary based model, Remote Sens. Environ., 112(1), 132-141, 2008.

Webb, E. K.: Profile relationships: The log-linear range and extension to strong stability, Quart. J. Roy. Meteor. Soc., 96, 67-90, 1970 .

Wu, B. and Ci, L. J.: Landscape change and desertification development in the Mu Us Sandland, Northern China, J. Arid Environ., 50, 429-444, 2002.

Wushenqi Chorography: Inner Mongolia Peoples Publishing House, Huhhot, 1-89, 2001.

$\mathrm{Xu}, \mathrm{C}$. Y. and Singh, V. P.: Evaluation of three complementary relationship evapotranspiration models by water balance approach to estimated actural regional evpotranspiration in different climate regions, J. Hydrol., 308, 105-121, 2004.

Yang, K., Koike, T., and Yang, D.: Surface flux parameterization in the Tibetan Plateau. Bound.-Lay. Meteorol., 116, 245-262, 2003.

Yang, X., Zhang, K., Jia, B., and Ci, L.: Desertification assessment in China: An overview, J. Arid Environ., 63, 517-531, 2005.

Yao, H., Wei, C., and Liao, M.: An introduction on the Mu Us Desert exploitation and control research center. Collected Papers of the Mu Us Desert Exploitation and Control Research Center, Inner Mongolia University Press, Hohhot, 1-7, 1992(in Chinese, abstract in English).

Yu, Y., Hu, X. L., Gao, Y., Zhang, W. J., Fan, W. Y., and Tengge A.: Study on fluctuations of groundwater level in the Mu Us Desert, Inner Mongolia For. Sci. Technol., 2, 8-12, 1998(in Chinese).

Zeng, Y.: Distributed modeling of actual evapotranspiration over rugged terrain of Yellow River Basin, Ph. D. Thesis, Institute of Geographic Sciences and Natural Resources Research, Beijing, 123 pp., 2004(in Chinese, abstract in English).

Zhang, Y. Q., Liu, C. M., Yu, Q., Shen Y. J., Kendy, E., Kondoh, A., Tang, C. Y., and Sun, H. Y.: Energy fluxes and the PriestleyTaylor parameter over winter wheat and maize in the North China Plain, Hydrol. Process., 18, 2235-2246, 2004. 